\title{
AGRICULTURAL AND WATERING SYSTEM OF SAMARKAND IN THE SECOND HALF OF THE XIX CENTURY AND THE EARLY XX CENTURY
}

\section{U.A. Usarov}

Phd Researcher Of Department Of "History Of Uzbekistan" Of The National University Of Uzbekistan

\section{N.O. Alimova}

Phd, Fergana State University, Uzbekistan

\section{ABSTRACT}

This article analyzes agricultural and land-water relations in the second half of the XIX and early XX centuries of Samarkand region on the basis number of sources, literature and research studies. The article provides information about the Zarafshan River, which was the region's main source of irrigation its tributaries and other water systems. There were presented traditions of irrigated agriculture in the region, types of agricultural products, rules of their cultivation, irrigation procedures and harvest time. The article also analyzes the agrarian policy of the Russian Empire which is connected with colonial interests in the Samarkand region and its consequences.

KEYWORDS: - Samarkand region, Russian empire, Zarafshan River, Karadarya, Akdarya, canal, ditch, agriculture, irrigated farming, non irrgated lands, cotton, wheat, rice, corn, gardening, grape, pood, desiatin, tanob, ko'sh.

\section{INTRODUCTION}

Samarkand was one of the most fertile, wellwatered areas of the Zarafshan oasis with an advanced farming culture from the ancient time. Irrigated agriculture has been developed in the area since the hard work of local farmers. Here, wheat, barley, rice, millet, sesame, corn, cotton, and other crops were planted and yielded 2-3 times a year. In the middle of the XIX century, the territory of Samarkand was one of the most developed and highly productive, rich natural resources within the Bukhara Emirate.

\section{THE MAIN RESULTS AND FINDING}

A number of sources of the second half of the XIX century give a wealth of information on the traditions and sectors of agriculture, irrigated agriculture that form the basis of Samarkand's economic life. In particular, according to N.M.Virskiy, "Samarkand region is located in the upper Zarafshan and its tributaries, with 6,828 acres of arable land, mostly adapted to artificial irrigation, and it was become to that shape due to hard work of the farmers [1, 7-8]. In the article "from Tashkent to Katta - Kurgana", N.M.Maev also reported on the territory of Samarkand where the Upper Zarafshan oasis is located. "The peoples of this river used water for irrigation of their lands. The road to the Kattakurgan hill on the Choponata hill at the entrance to Samarkand is well-watered and green. The upper part of the Zarafshan valley was fertile and was well 
CURRENT RESEARCH JOURNAL OF HISTORY 2(7): 09-14, July 2021

DOI: https://doi.org/10.37547/history-crjh-02-07-03

ISSN 2767-472X

(C)2021 Master Journals

\section{Crossref do) 81 Google}

Accepted 05th July, 2021 \& Published 10thJuly, 2021

watered" [2,198-219]. As the above data shows, the existing countries have consistently strived to maintain this region due to its great economic potential.

In the second half of the XIX century the population of Samarkand region was mainly engaged in agriculture in everyday life. $1.3 \%$ of the total population of Samarkand region (18681870) lived in urban areas, and in 1897 only $15.7 \%$. In $189780.1 \%$ of the total population of the region was occupied by agriculture. In addition, the share of trade and industry workers was $15.4 \%[3,310]$. Consequently, livelihoods of the people of the region were mainly related to agriculture, and irrigation was the main occupation of the population.

Due to the varied natural and geographical conditions of the Samarkand region, various methods of irrigation are widely used in agriculture. For example, water was brought to the fields by collecting water from pools, digging canals and ditches. The ditches and canals are taken from the Zarafshan River, the main source of water in the province, or from the Karadarya, Akdarya, Narpay and other water systems that have separated from it. Such measures allowed the fertility of the Samarkand region lands [4, 65].

In the second half of the XIX century, 56 canals were dug from the Zarafshan River, the main source of water in the Samarkand region, of which 42 irrigated the Panjikent and Samarkand sections and 14 the Kattakurgan section[26, -P. 4.]. The total irrigated area of these lands through these canals was 9893.79 kushes (1 kush - about 13,02 deciatine) or 128,818.75 deciatine (1.09 ha per 1 hectare). Including, in the Samarkand section 7410.25 double or 96487.5 deciles were irrigated, and in Kattakurgan section 2443.53 double or 32331.25 deciles were irrigated. In 1888 a total of 142 main canals were taken from the Zarafshan
River. Of these, 99 provided water to the Samarkand region and 43 to the Bukhara Emirate. There were 1, 924 in the Zarafshan oasis, 985 out of the secondary canals, and 939 in the Bukhara section $[5,202]$. It is clear that the Russian Empire has taken full control of the distribution of water, first and foremost in the Samarkand region and then the Zarafshan River.

In irrigated agriculture, a number of hydrotechnical structures, such as dams and waterfowl, have been built in the slopes of the river using natural resources such as nranchess, turfs, boulders. Therefore, the area's agricultural lands were fertile and the population was engaged in cotton growing, grain growing, vegetable growing and gardening. In the Zarafshan oasis, especially in the Samarkand region, two types of crops have been cultivated, depending on the season. The first is "autumn or white", a fall crop, which includes barley, wheat, flax, poppy and more. The second was the spring crop, which includes corn, rice, millet, moss, peas, beetroot, carrots, onions, turnips, tobacco and others. In addition, cottwere regularly planted in the valley.

In the second half of the XIX century, a total of 32 different types of agricultural crops, including potatoes, were cultivated in Zarafshan district $[6,203]$. Potato cultivation, like other regions of Central Asia, was brought to Zarafshan by Russian-speaking populations.

In the second half of the XIX - beginning of the XX century, peasants used 'crop rotation' to increase the productivity of irrigated land in the Zarafshan oasis, especially in the Samarkand region. At the same time, the area under one sown area was cultivated and rested for a period of time without any other sowing. For example, in Bulungur district of the region, the area of irrigated land above the Zarafshan River was 5.5 thousand hectares. Of this, about 3,200 hectares are cultivated annually and the rest of the 
CURRENT RESEARCH JOURNAL OF HISTORY 2(7): 09-14, July 2021

DOI: https://doi.org/10.37547/history-crjh-02-07-03

ISSN 2767-472X

(C)2021 Master Journals

\section{Crossref do) 81 Google}

Accepted 05th July, 2021 \& Published 10 th July, 2021

farmland was rested [7, 16-17]. In addition, soil fertility in the area has been continuously increased through local fertilizers and crop rotation.

The main occupation of the population of Turkestan during this period in the Ferghana, Syrdarya and Samarkand regions agriculture was well developed. Since most of the farmland is irrigated the construction, maintenance and operation of various waterworks has been done with public participation. However, heavy manual labor was very important in agricultural production, modern machinery and equipment were virtually non-existent [27, -P. 514].

As a result of the Russian Empire's reign, agricultural production in the Samarkand region was largely focused on cotton production. This was due to the increase in textile enterprises in Russia and the increased demand for Turkestan cotton. It was also intended to make Turkestan, including Samarkand region, a major raw cotton supplier. As a result, colonial industries expanded their activities.

According to I.M. Slutsky, in the second half of the 19th century, Chelak, Yangikurgan in Samarkand district; $75 \%$ of the cotton grown in $1885-1900$ was given to the first grade and $25 \%$ to the second grade, due to good climatic conditions in Khatyarik, Thursday, Damarik and Kalghurgan districts of Kattakurgan district. It also highlights that in Samarkand region, the income of farmers from cotton is on the 4 th place among agricultural crops $[8,55]$. Cotton has been planted in $1 / 15$ of the total arable land in the region $(36,400$ deci- sions account for 24,280 decyatins) $[9,68]$. In general, cotton was sown in the province for three years, and the land was well fertilized. Then the alfalfa and other plants were planted. In other words, a great deal of attention was paid to the method of crop rotation $[10,174-175]$.

According to 1889 , the major agricultural regions in Samarkand province were Mitan, Chelak, Kattakurgan and Khujand [11, 109], and in 1900 and 1908 Kattakurgan, Samarkand and Jizzakh counties were the main cotton producing regions. The districts of Kattakurgan, Samarkand and Jizzakh produced 472,282 pounds of cotton in $1900,651,285$ pounds in 1905 , and 585,724 pounds of cotton in 1908. At the same time, the crop accounts for more than half of the cotton grown in the whole region $[12,177]$.

Cotton planting in Samarkand region tripled from 1888 to 1908 . If in 1888 the area under cotton was 8,000 deciatine, in 1907 it was 28,000 deciats, in 1913 - 31,800, in $1914-30,800$, and in 1915 - 55,600. [13, 29 ], 60,300 decyatines in 1916, and 42,000 deciles in 1917 [14, 178].

The amount of cotton harvested in the region amounted to $1,555,139$ in $1900,1,118,105$ in $1905,901,565$ in 1908, 953,000 in 1913, 621,000 in $1914,1,346,000$ in 1915 , and 826,000 in 1917 $[14,178]$. The main cotton crop grown in all these years was located in the European part of Russia and delivered to new factories and factories.

Grain crops, the main food for the population of Samarkand region, also played a major role in agricultural production. The region had a large crop of wheat, barley, corn and rice. Prior to the invasion of the Russian Empire, these areas of the Bukhara Emirate provided themselves with domestic products, including wheat, corn and rice. In Zarafshan County, wheat was sown mainly in September-November and was irrigated once in April and twice in May [16, 202203]. Then, in early June, the crop was harvested.

In the second half of the 19th century, farmers in the Samarkand region harvested from the ground up to two times a year. After harvesting the winter wheat, they planted melons. The melons were harvested in the fall and planted in spring. Some of the land that was sown in spring was sown with wheat and partly barley. Wheat 
CURRENT RESEARCH JOURNAL OF HISTORY 2(7): 09-14, July 2021

DOI: https://doi.org/10.37547/history-crjh-02-07-03

ISSN 2767-472X

(C)2021 Master Journals

\section{Crossref do) 81 Google}

Accepted 05 ${ }^{\text {th }}$ July, 2021 \& Published 10thJuly, 2021

was irrigated up to three times. One pound of well-cultivated land yields 40 poods ( 1 pood - 16 $\mathrm{kg}$ ) of wheat and an average of 32 pood per acre $[17$, 419-447]. After the farmers harvested barley and wheat, they prepared the soil for planting. Then planted peanuts, sesame seeds, carrots, mash, beans, peas.

According to X.Ziyaev, in the second half of the XIX century, a total of 2.057.008 deciles of land was cultivated in Turkestan. Of these, 824.903 have been planted with wheat. However, due to the intensification of the cotton monoculture in Turkestan, especially in the Samarkand region, wheat has been mainly cultivated on dry, nonirrigated rainfed lands [18,177-178]. Farmers in the area paid much attention to early or late wheat harvest in order to get good harvest from rain-fed lands. He paid much attention to how the weather came and how it was planted. During the favorable weather years, 1 hectare of sown wheat land yielded

100 poods of grain and more in a well-selected area. The amount of seeds sown in each desiccate does not exceed 2-3 poods. Such land has always been priced in the market at a higher price than wheat from the fields. In the eastern part of Samarkand province, rainfall has always been better than in Ziyovuddin Station $[19,41]$. This was partly due to the fact that the agricultural population of the region has developed a culture of farming.

At the end of XIX century Zarafshan district was divided into 13 districts. Of these, there were many ditches in Miyanqol district. Here, agriculture was prosperous and was the foremost producer. Sogdian Kalon and Shovdor districts occupy the next post-Miyonkol issue. In Samarkand, cotton, wheat, rice, millet, corn, barley, flax, moss, peas were planted. The most productive area of Zarafshan district iwas Ofarikent $[20,60]$.

Due to the sufficiency of water supply in the
Samarkand region, cultivation of high-water rice was specific. The rice was grown in Shavdor, Shiroz, Ofarinkent, Sughut, Kattakurgan, Yangikurgan and Payshanba districts of Zarafshan district $[21,203]$. Here, in May, two pods of seeds were sown in a rice field and watered continuously for 90 days. The crop was harvested in late September - early October, with 32 to 80 poods harvested from each well [22, 76]. The main areas for rice cultivation in Samarkand and Kattakurgan districts were the Miyankol lands, located between the Akdarya and Kara-Darya, which separated from the Zarafshan River. For example, 21 out of 26 districts in Samarkand, 11 out of 17 in Kattakurgan district, and 6 in Khujand district. In 1907 , rice was planted on 43,513 desyatin lands in the region. Of these, 4112 were in Kattakurgan district, 36935 in Samarkand district, and 2666 in Khujand district. This accounts for $6.2 \%$ of the total irrigated land in the Kattakurgan district, $14.3 \%$ in the Samarkand district, and $8 \%$ in the Khujand district [23, 1-2]. In addition, corn, millet, beetle, and flax have been planted in Zarafshan District, which require high water consumption.

In the second half of the XIX century, gardening was well established in the region, among which viticulture was the first and most profitable. According to AI Shahnazarov, 6,225,000 puds were harvested from the 19,282 land plots in Turkestan during the same period. Of these, $5,197,000$ pods are grown in the Samarkand region [24, 240]. In 1894, 252979 poods of grapes were transported from the Samarkand region to the markets of the Russian Empire by rail, and 150,000 poods of grapes were transported by caravan. Samarkand region also played an important role in exporting dried fruit to Russia. In 1907, for example, 1,915 tonnes of plum tons were seized. Samarkand region was the leader in the production of dried fruit, especially black raisins $[25,146]$. 
CURRENT RESEARCH JOURNAL OF HISTORY 2(7): 09-14, July 2021

DOI: https://doi.org/10.37547/history-crjh-02-07-03

ISSN 2767-472X

(C)2021 Master Journals

Crossref doi 80 Google

Accepted 05th July, 2021 \& Published 10 th July, 2021

\section{Conclusion}

Generally, in the second half of the XIX century, the Russian Empire established its rule in Turkestan, particularly in the Samarkand region. He implemented agrarian policy in the region based on colonial interests. Samarkand region had access to water from large tributaries from the upper part of the Zarafshan River. As a result, irrigated agriculture was developing in the region. However, these successes served the interests of more colonialists. The region's agricultural products were exported to the Russian Empire. The demand for Turkestan cotton has increased as Russian industrial enterprises increase. As a consequence, the Samarkand region's specialization in cotton cultivation on irrigated land has developed rapidly. This has had a negative impact on other agricultural sectors of the region.

Continuous expansion of cotton growing in Turkestan, especially in Samarkand region, resulted in economic crisis in the first decade of the twentieth century as a result of one-sided approach to agriculture $[15,242]$. This has worsened the social situation of not only the farmers but also the entire population. Demand for food and cereals has been increasing day by day. In the markets, however, prices have increased. In spite of these difficulties, local farmers have been trying to satisfy the demand of the population by producing as many products as possible.

\section{ReFERENCES}

1. Virsky N.M. Viticulture in the Samarkand district. Samarkand Regional Statistical Committee. - Samarkand, 1893 .-Pp. 7-8.

2. Maev N.M. From Tashkent to Katta-Kurgan // Tkukestansaya collection. - SPb,
1870.Vol. 34 .-Pp. 198-219.

3. 3Kuraxmedov A.E. The second half of the XIX century - economic and cultural life in the Samarkand region in the early XX century (based on the data of the Turkestan collection). - Samarkand. 2001. p. 65.

4. Muhammadjonov A.R. History of irrigation of the Lower Zarafshan valley (from ancient times to the beginning of the XX century). - T .: Fan, 1972. - P. 202.

5. Toshev X. The economy and social life of the Zarafon Uzbeks in the late 19th and early 20 th centuries. - T .: Fan, 1987. - Pp. 16-17.

6. 6. Slutskiy I.M. Essay on cotton growing in the Samarkand region // Turkestan collection. - T .: 1909.T. 527 .-P. 55.

7. Kuraxmedov A.E. The second half of the XIX century - economic and cultural life in the Samarkand region in the early XX century (based on the data of the Turkestan collection). - Samarkand, 2001. P. 68.

8. Ziyoev X.Z. History is a mirror of the past and the future. - $\mathrm{T}$.: Literature and art, 2000. - Pp. 174-175.

9. Yuldashev A. Agrarian relations in Turkestan (late XIX - early XX centuries). T .: Uzbekistan, - p. 109

10. Ziyoev H.Z. History is a mirror of the past and the future. - $\mathrm{T}$.: Literature and art, 2000. - P. 177.

11. Socio-economic and political situation in Uzbekistan on the eve of October. - T .: Fan, 1973 .-P. 29.

12. Ziyoev H.Z. History is a mirror of the past and the future. - $\mathrm{T}$.: Literature and art, 2000. - Pp. 177-178. 
CURRENT RESEARCH JOURNAL OF HISTORY 2(7): 09-14, July 2021

DOI: https://doi.org/10.37547/history-crjh-02-07-03

ISSN 2767-472X

(C)2021 Master Journals

Crossref do: 81 Google

Accepted 05 ${ }^{\text {th }}$ July, 2021 \& Published 10thJuly, 2021

13. New history of Uzbekistan. Turkestan during the independence of Tsarist Russia. -T .: Sharq, 2000. - P. 242.

14. Muhammadjonov A.R. History of irrigation of the Lower Zarafshan valley (from ancient times to the beginning of the XX century). - T .: Fan, 1972. - Pp. 202-203.

15. Ziyoev H.Z. History is a mirror of the past and the future. - $\mathrm{T}$.: Literature and Art, 2000. - P. 177-178.

16. Ziyoev H.Z. History is a mirror of the past and the future. - T .: Literature and art, 2000. - Pp. 177-178.

17. Toshev X. The economy and social life of the Zarafon Uzbeks in the late 19th and early 20th centuries. - T .: Fan, 1987. - P. 41.

18. Pardaev K.K. Socio-political, economic and cultural life of the Middle Zarafshan (Miyankol) oasis in the XIX - early XX centuries. - T .: 2003. - P. 60.

19. Muhammadjonov A.R. History of irrigation of the Lower Zarafshan valley (from ancient times to the beginning of the XX century). - T .: Fan, 1972. - P. 203.

20. Kuraxmedov A.E. The second half of the XIX century - economic and cultural life in the Samarkand region in the early XX century (based on the data of the Turkestan collection). - Samarkand. 2001. P. 76.

21. Rice culture and its economic importance in the Samarkand region // Reference book of the Samarkand region. Issue IX. Samarkand: 1907 .-Pp. 1-2.

22. Shakhnazarov A.I. Agriculture in the Turkestan Territory. - S-Pb. 1908 .-- P. 240.

23. Witnesses and lessons of history: the development of national wealth of
Uzbekistan in the period of tsarism and Soviet colonialism. - T .: Sharq, 2001. - P. 146.

24. Usarov U.A. Irrigation system of Turkestan in the second half of 19th century and early 20th century / The American Journal of Social Science and Education Innovations. Volume 03 Issue 06-2021. -P. 1-7.

25. Usarov, U. A. (2019). Some considerations on the pecularities of Russian empire's politics in Turkestan. ISJ Theoretical \& Applied Science, 12 (80), 514. 